\title{
EFFECT OF FERTILIZER PACKAGES ON BROADCAST AUS RICE IN LENTIL-B. AUS-BLACKGRAM CROPPING PATTERN IN THE CHAR LAND OF PABNA IN BANGLADESH
}

\author{
M. Maniruzzaman ${ }^{1 *}$, M. R. Alam ${ }^{1}$, M.S. Islam ${ }^{1}$, M.Z. Islam ${ }^{1}$, M.S.H. Molla ${ }^{2}$ and M.A. Islam ${ }^{3}$ \\ ${ }^{1}$ On-farm Research Division, Bangladesh Agricultural Research Institute, Pabna \\ ${ }^{2}$ On-farm Research Division, Bangladesh Agricultural Research Institute, Rangpur \\ ${ }^{3}$ On-farm Research Division, Bangladesh Agricultural Research Institute, Shampur, Rajshahi \\ *Corresponding author, E-mail: maniruzzaman.bari@yahoo.com
}

(Received: 21 December 2017, Accepted: 5 February 2018)

Keywords: Yield, mixed cropping, gross return, total variable cost and gross margin

\begin{abstract}
The experiment was conducted at Char Sadipur in the char land of Pabna during Aus rice seasons of 2014 and 2015 to determine appropriate fertilizer dose for enhancing yield of B. Aus rice var. Hashikalmi and also to increase farmers' income in char land under High Ganges River Floodplain (AEZ-11). The experiment was laid out in a randomized complete block design with four dispersed replications. Eight fertilizer packages $\mathrm{T}_{1}: \mathrm{N}_{40} \mathrm{P}_{9} \mathrm{~K}_{16} \mathrm{~S}_{6} \mathrm{Zn}_{1}(\mathrm{STB}), \mathrm{T}_{2}: \mathrm{N}_{50} \mathrm{P}_{9} \mathrm{~K}_{16} \mathrm{~S}_{6} \mathrm{Zn}_{1}, \mathrm{~T}_{3}: \mathrm{N}_{50} \mathrm{P}_{11} \mathrm{~K}_{16} \mathrm{~S}_{6} \mathrm{Zn}_{1}, \mathrm{~T}_{4}$ : $\mathrm{N}_{50} \mathrm{P}_{9} \mathrm{~K}_{20} \mathrm{~S}_{6} \mathrm{Zn}_{1}, \mathrm{~T}_{5}: \mathrm{N}_{40} \mathrm{P}_{11} \mathrm{~K}_{20} \mathrm{~S}_{6} \mathrm{Zn}_{1}, \mathrm{~T}_{6}: \mathrm{N}_{50} \mathrm{P}_{11} \mathrm{~K}_{20} \mathrm{~S}_{6} \mathrm{Zn}_{1}, \mathrm{~T}_{7}: \mathrm{N}_{30} \mathrm{P}_{7} \mathrm{~K}_{12} \mathrm{~S}_{4.5} \mathrm{Zn}_{0.75} \mathrm{~kg} \mathrm{ha}^{-1}$ and $\mathrm{T}_{8}$ : Native nutrients (control) were tested for B. Aus rice in Lentil-B. AusBlackgram cropping pattern. The treatment $\mathrm{N}_{50} \mathrm{P}_{11} \mathrm{~K}_{20} \mathrm{~S}_{6} \mathrm{Zn}_{1}\left(\mathrm{~T}_{6}\right)$ produced maximum grain yield $2.60 \mathrm{t} \mathrm{ha}^{-1}$ and $2.81 \mathrm{t} \mathrm{ha}^{-1}$ of B. Aus rice in 2014 and 2015 cropping season, respectively. The highest gross return (Tk. $61,810 \mathrm{ha}^{-1}$ in 2014 and Tk. 72,250 ha $\mathrm{ha}^{-1}$ in 2015 cropping season) and gross margin (Tk. 12,214 ha- in 2014 and Tk. 21,550 ha-1 in 2015 cropping season) was also recorded from $\mathrm{N}_{50} \mathrm{P}_{11} \mathrm{~K}_{20} \mathrm{~S}_{6} \mathrm{Zn}_{1}\left(\mathrm{~T}_{6}\right)$ and lowest from control in both the years.
\end{abstract}

\section{Introduction}

Bangladesh is the fourth largest producer and consumer of rice in the world. Rice is the primary staple food and the most important crop. Rice is extensively grown in Bangladesh which covers $75 \%$ of the total cropped area and about $60 \%$ labor is engaged in rice production. It was estimated 34.8 million metric tons in the year 2014 among all cereals in Bangladesh (BBS, 2015). Rice alone contributes around $10 \%$ to the GDP and $95 \%$ to the total food grain production (BER, 2010).It contains a number of energy rich compounds such as carbohydrates, fat, protein and reasonable amount of vitamins (Nadeem et al., 2010). The national mean yield $\left(2.60 \mathrm{tha}^{-1}\right)$ of rice in Bangladesh is lower than the potential national yield $\left(5.40 \mathrm{t} \mathrm{ha}^{-1}\right)$ and world average yield (3.70 t ha-1) (Pingali et al., 1997). The lower yield of rice has been attributed to several reasons. Most of the soils in Bangladesh are deficient in N, P, K, S and Zn for rice cultivation. Moreover, soil fertility is declining further due to intensive cropping and imbalanced use of fertilizers by the farmers (Biswas et al., 2001). As a result, growth and yield of rice is also declining in many cases. Balance fertilization is, therefore, usually needed.

In Bangladesh, the lands of char area are not suitable for growing many crops and all seasons for low water holding capacity of the soils. In Pabna, there is a vast area of char land under AEZ-11. Nutrient status of char land is poor due to coarse textured soils, low water holding capacity, low nutrient content, river bank erosion and flooding. Farmers of char land in Pabna generally grow B. aus rice where they use local variety with no or limited fertilizers. For this 
reason, the yield of $\mathrm{B}$. Aus rice in this region is much below than that of potential yield level. Balanced fertilization can play a major role to enhance the present yield level. Experimental evidences reveal that the crop is highly responsive to different fertilizers and its yield can be increased remarkably through judicious fertilization (Mohamed, 1984; Roy and Singh, 1986; Kazi et al., 2002). Fertilizer recommendation solely based on crop response data often fails to show economic viability. In this context, Perrin et al. (1979) reported that response of yield should be supported by economic evaluation for judicious fertilizer recommendation. Since the application of balance fertilizer is important for increasing the yield of B. aus rice and very limited information in this regard is available for char areas, the present study was undertaken to determine the optimum fertilizer dose for maximizing B. Aus rice yield in the char land areas of Pabna.

\section{Materials and methods}

The experiment was conducted at the char land of Char Sadipur areas of Pabna in Bangladesh during the Aus rice seasons of 2014 and 2015. The experimental site was under Gopalpur soil series of the High Ganges River Floodplain (AEZ-11). Before starting the experiment, initial composite soil samples $(0-15 \mathrm{~cm}$ depth) were collected from the experimental plots and were analyzed in the laboratory. The analytical result indicated that soil was sandy loam with very low organic matter content $(0.80 \%)$ and slightly alkaline in nature. $\mathrm{N}$ content of soil was very low and $\mathrm{P}, \mathrm{S}$ and $\mathrm{Zn}$ content of the soil were low. K content of the soil was medium (Table 1). The experiment was laid out in randomized complete block (RCB) design with three replications. The unit plot size was $5 \mathrm{~m} \times \mathrm{x} 4 \mathrm{~m}$. Eight treatments consisted of $\mathrm{T}_{1}: \mathrm{N}_{40} \mathrm{P}_{9} \mathrm{~K}_{16} \mathrm{~S}_{6} \mathrm{Zn}_{1}$ (STB), $\mathrm{T}_{2}: \mathrm{N}_{50} \mathrm{P}_{9} \mathrm{~K}_{16} \mathrm{~S}_{6} \mathrm{Zn}_{1}, \mathrm{~T}_{3}: \mathrm{N}_{50} \mathrm{P}_{11} \mathrm{~K}_{16} \mathrm{~S}_{6} \mathrm{Zn}_{1}, \mathrm{~T}_{4}: \mathrm{N}_{50} \mathrm{P}_{9} \mathrm{~K}_{20} \mathrm{~S}_{6} \mathrm{Zn}_{1}, \mathrm{~T}_{5}: \mathrm{N}_{40} \mathrm{P}_{11} \mathrm{~K}_{20} \mathrm{~S}_{6} \mathrm{Zn}_{1}, \mathrm{~T}_{6}$ : $\mathrm{N}_{50} \mathrm{P}_{11} \mathrm{~K}_{20} \mathrm{~S}_{6} \mathrm{Zn}_{1}, \mathrm{~T}_{7}: \mathrm{N}_{30} \mathrm{P}_{7} \mathrm{~K}_{12} \mathrm{~S}_{4.5} \mathrm{Zn}_{0.75} \mathrm{~kg} \mathrm{ha}^{-1}$ and $\mathrm{T}_{8}$ : Native nutrients (control) were used in the experiment. The land was prepared by power tiller followed by laddering. After completion of land preparation the entire amount of $\mathrm{P}, \mathrm{K}, \mathrm{S}, \mathrm{Zn}$ and $1 / 3 \mathrm{~N}$ were applied as per treatment specification TSP, MP, Gypsum, Zinc sulphate and urea, respectively.

Table 1.Nutrient status of the initial soil sample $(0-15 \mathrm{~cm}$ depth) of experimental plots at Char Sadipur, Pabna

\begin{tabular}{lcc}
\hline Soil properties & Values & Interpretation \\
\hline Soil $\mathrm{pH}$ & 8.1 & Slightly alkaline \\
Organic matter content $(\%)$ & 0.80 & Very low \\
Total N $(\%)$ & 0.05 & Very low \\
Available $\mathrm{P}(\mu \mathrm{g} / \mathrm{g}$ soil $)$ & 11.8 & Low \\
Available S $(\mu \mathrm{g} / \mathrm{g}$ soil $)$ & 9.2 & Low \\
Available $\mathrm{Zn}(\mu \mathrm{g} / \mathrm{g}$ soil $)$ & 0.57 & Low \\
Exchangeable K (meq \%) & 0.16 & Medium \\
\hline
\end{tabular}

The seeds of B. Aus rice were broadcasted in each plot on 3-5 May, 2014 \& 2015 maintaining the seed rate of $50 \mathrm{~kg} \mathrm{ha}^{-1}$ in both the seasons. The variety used for the trial was local Hashikalmi. 50\% $\mathrm{N}$ was applied as basal and the rest amount of $\mathrm{N}$ was top dressed in two splits at 25 and 45 Day After Sowing (DAS) in the form of urea. Two times weeding were done at vegetative stage for better growth of the crops. Other intercultural operations such as insect and disease management were done as and when necessary. The rice was harvested on 15-20 August, $2014 \& 2015$. Necessary data on yield and yield components were collected at proper maturity of the crop. All the recorded data were statistically analyzed using a statistical package MSTAT program of computer and the means differences were adjudged by LSD test. Cost and return analysis of different treatments were done. 


\section{Results and Discussion}

Plant height and yield contributing characters of B. Aus rice have been presented in Table 2 . Significant variation in respect of plant height, effective tiller hill- ${ }^{-1}$, number of panicle $\mathrm{m}^{-2}$ and filled grains panicle ${ }^{-1}$ were observed due to different treatments. Maximum plant height (122.4cm in 2015 and $96.7 \mathrm{~cm}$ in 2014), effective tiller hill ${ }^{-1}$ (9.6 in 2015 and 5.73 in 2014), number of panicle $\mathrm{m}^{-2}$ (357.7 in 2015 and 267.67in 2014) and filled grains panicle ${ }^{-1}(64.3$ in 2015 and 55.32 in 2014) were recorded from $\mathrm{N}_{50} \mathrm{P}_{1} \mathrm{~K}_{20} \mathrm{~S}_{6} \mathrm{Zn}_{1}\left(\mathrm{~T}_{6}\right)$ and minimum plant height $\left(112.3 \mathrm{~cm}\right.$ in 2015 and $85.57 \mathrm{~cm}$ in 2014), effective tiller hill ${ }^{-1}$ (7.17 in 2015 and 4.1 in 2014), number of panicle $\mathrm{m}^{-2}$ (275.3 in 2015 and 197.33 in 2014) and filled grains panicle ${ }^{-1}(37.53$ in 2015 and 35.49 in 2014) were recorded from control $\left(\mathrm{T}_{8}\right)$ treatment. In case of plant height similar finding was recorded by Haque et. al. (2016) and Li et. al. (1997), who stated that plant height increased significantly because of increasing fertilizer. The increase in plant height because of application of increased level of fertilizer might be associated with stimulating effect of fertilizer on various physiological processes. Adequacy of optimum fertilizer probably favored the cellular activities during the development and grain formation which lead to increased number of effective tillers hill ${ }^{-1}$ and number of grains panicle ${ }^{-1}$. Haque et. al. (2016) also reported that application of soil test best fertilizer showed better response on effective tillers production and number of grains.

Table 2. Plant height and yield contributing parameters of B. Aus at Charsadipur, Pabna during 2014 and 2015 cropping seasons

\begin{tabular}{lcccccccc}
\hline \multirow{2}{*}{ Treatments } & \multicolumn{2}{c}{ Plant height $(\mathrm{cm})$} & \multicolumn{2}{c}{$\begin{array}{c}\text { Effective tiller } \\
\text { hill }^{-1}\end{array}$} & \multicolumn{2}{c}{$\begin{array}{c}\text { No. of panicle } \\
\left(\mathrm{m}^{-2}\right)\end{array}$} & \multicolumn{2}{c}{$\begin{array}{c}\text { Filled grains } \\
\text { panicle }^{-1}\end{array}$} \\
\cline { 2 - 9 } & 2014 & 2015 & 2014 & 2015 & 2014 & 2015 & 2014 & 2015 \\
\hline $\mathrm{T}_{1}$ & 88.63 & 117.0 & 5.20 & 7.86 & 228.33 & 312.0 & 41.43 & 56.17 \\
$\mathrm{~T}_{2}$ & 89.33 & 118.0 & 5.33 & 8.45 & 244.67 & 335.3 & 45.19 & 56.70 \\
$\mathrm{~T}_{3}$ & 91.57 & 117.4 & 5.63 & 8.86 & 244.67 & 341.3 & 43.54 & 57.77 \\
$\mathrm{~T}_{4}$ & 90.77 & 116.9 & 5.00 & 8.73 & 244.33 & 341.7 & 45.21 & 61.57 \\
$\mathrm{~T}_{5}$ & 90.13 & 119.8 & 5.67 & 8.69 & 260.33 & 343.7 & 49.89 & 58.27 \\
$\mathrm{~T}_{6}$ & 96.70 & 122.4 & 5.73 & 9.60 & 267.67 & 357.7 & 55.32 & 64.30 \\
$\mathrm{~T}_{7}$ & 87.00 & 115.1 & 4.30 & 7.70 & 232.00 & 298.0 & 38.63 & 50.70 \\
$\mathrm{~T}_{8}$ & 85.57 & 112.3 & 4.10 & 7.17 & 197.33 & 275.3 & 35.49 & 37.53 \\
\hline $\mathrm{LSD}(0.05)$ & 5.331 & 3.21 & 0.75 & 0.83 & 16.55 & 25.13 & 6.68 & 10.17 \\
$\mathrm{CV}(\%)$ & 2.44 & 1.56 & 9.36 & 5.68 & 2.84 & 4.41 & 8.61 & 7.55 \\
\hline
\end{tabular}

Note: $\mathrm{T}_{1}: \mathrm{N}_{40} \mathrm{P}_{9} \mathrm{~K}_{16} \mathrm{~S}_{6} \mathrm{Zn}_{1}(\mathrm{STB}) ; \mathrm{T}_{2}: \mathrm{N}_{50} \mathrm{P}_{9} \mathrm{~K}_{16} \mathrm{~S}_{6} \mathrm{Zn}_{1} ; \mathrm{T}_{3}: \mathrm{N}_{50} \mathrm{P}_{11} \mathrm{~K}_{16} \mathrm{~S}_{6} \mathrm{Zn}_{1} ; \mathrm{T}_{4}: \mathrm{N}_{50} \mathrm{P}_{9} \mathrm{~K}_{20} \mathrm{~S}_{6} \mathrm{Zn}_{1}$;

$\mathrm{T}_{5}: \mathrm{N}_{40} \mathrm{P}_{11} \mathrm{~K}_{20} \mathrm{~S}_{6} \mathrm{Zn}_{1} ; \mathrm{T}_{6}: \mathrm{N}_{50} \mathrm{P}_{11} \mathrm{~K}_{20} \mathrm{~S}_{6} \mathrm{Zn}_{1} ; \mathrm{T}_{7}: \mathrm{N}_{30} \mathrm{P}_{7} \mathrm{~K}_{12} \mathrm{~S}_{4.5} \mathrm{Zn}_{0.75} \mathrm{~kg}{ }^{-1} ; \mathrm{T}_{8}$ : Control

Thousand-seed weight, yield and percent yield increase over control of B. Aus rice have been presented in Table 3. The highest 1000 -grain weight (23.25g in 2015 and $23.8 \mathrm{~g}$ in 2014) was observed from $\mathrm{N}_{50} \mathrm{P}_{11} \mathrm{~K}_{20} \mathrm{~S}_{6} \mathrm{Zn}_{1}\left(\mathrm{~T}_{6}\right)$ and the lowest 1000 -seeds weight (22.08g in 2015 and $22.77 \mathrm{~g}$ in 2014) from control $\left(\mathrm{T}_{8}\right)$ treatment. Maximum straw yield of $\mathrm{B}$. Aus rice $\left(5.65 \mathrm{t} \mathrm{ha}^{-1}\right.$ in 2015 and $3.27 \mathrm{t} \mathrm{ha}^{-1}$ in 2014) was found from $\mathrm{N}_{50} \mathrm{P}_{11} \mathrm{~K}_{20} \mathrm{~S}_{6} \mathrm{Zn}_{1}\left(\mathrm{~T}_{6}\right)$ treatment which was statistically different from all other treatments and minimum straw yield $\left(3.6 \mathrm{t} \mathrm{ha}^{-1}\right.$ in 2015 and $1.73 \mathrm{t} \mathrm{ha}^{-1}$ in 2014) was control $\left(\mathrm{T}_{8}\right)$. The highest seed yield $\left(2.81 \mathrm{t} \mathrm{ha}^{-1}\right.$ in 2015 and $2.6 \mathrm{t} \mathrm{ha}^{-1}$ in 2014) was attained from $\mathrm{N}_{50} \mathrm{P}_{11} \mathrm{~K}_{20} \mathrm{~S}_{6} \mathrm{Zn}_{1}\left(\mathrm{~T}_{6}\right)$ which was also statistically significant from all other treatments. On the contrary control $\left(\mathrm{T}_{8}\right)$ treatment provided the lowest seed yield $(1.55 \mathrm{t}$ $\mathrm{ha}^{-1}$ in 2015 and $1.5 \mathrm{t} \mathrm{ha}^{-1}$ in 2014). The cumulative contribution of potential yield traits might be the reason for higher grain yield from $\mathrm{N}_{50} \mathrm{P}_{11} \mathrm{~K}_{20} \mathrm{~S}_{6} \mathrm{Zn}_{1}\left(\mathrm{~T}_{6}\right)$. In contrast, poor crop growth and yield traits resulted the lowest grain yield in control $\left(\mathrm{T}_{8}\right)$. Maximum yield increased $(81 \%$ in 
2015 and $73 \%$ in 2014 ) over control was obtained from $\mathrm{N}_{50} \mathrm{P}_{11} \mathrm{~K}_{20} \mathrm{~S}_{6} \mathrm{Zn}_{1}\left(\mathrm{~T}_{6}\right)$. The overall results indicate that in char land conditions soils are dominated with sand particles and low organic matter which causes deficiency in nutrient availability in soil and make imbalance in subsequent plant uptake. Therefore, $100 \%$ soil test based fertilizer package plus $25 \%$ additional nutrients specially $\mathrm{N}, \mathrm{P}$ and $\mathrm{K}$ fertilizer dose $\mathrm{N}_{50} \mathrm{P}_{11} \mathrm{~K}_{20} \mathrm{~S}_{6} \mathrm{Zn}_{1}\left(\mathrm{~T}_{6}\right)$ enhance optimum plant growth and development and higher yield in $\mathrm{B}$. Aus rice. These results are supported by the findings of Das et. al. (2003). He reported that increasing levels of NPK application increased the yield attributing characters and nutrient uptake by the cereal crops, which ultimately increased the grain and straw yields.

Table 3. Yield and 1000- grain weight of B. Aus at Charsadipur, Pabna during 2014 and 2015 cropping season

\begin{tabular}{lcccccccc}
\hline \multirow{2}{*}{ Treatments } & \multicolumn{2}{c}{$\begin{array}{c}\text { 1000- grain weight } \\
(\mathrm{g})\end{array}$} & \multicolumn{2}{c}{$\begin{array}{c}\text { Straw yield } \\
\left(\mathrm{t} \mathrm{ha}^{-1}\right)\end{array}$} & \multicolumn{2}{c}{$\begin{array}{c}\text { Grain yield } \\
\left(\mathrm{t} \mathrm{ha} \mathrm{a}^{-1}\right)\end{array}$} & \multicolumn{2}{c}{$\begin{array}{c}\text { \% Yield increase } \\
\text { over control }\left(\mathrm{T}_{8}\right)\end{array}$} \\
\cline { 2 - 9 } & 2014 & 2015 & 2014 & 2015 & 2014 & 2015 & 2014 & 2015 \\
\hline $\mathrm{T}_{1}$ & 22.97 & 22.25 & 2.17 & 4.08 & 1.70 & 2.00 & 13 & 29 \\
$\mathrm{~T}_{2}$ & 23.00 & 22.43 & 2.32 & 4.38 & 1.78 & 2.13 & 19 & 37 \\
$\mathrm{~T}_{3}$ & 23.00 & 22.67 & 2.50 & 4.66 & 1.89 & 2.37 & 26 & 53 \\
$\mathrm{~T}_{4}$ & 23.30 & 22.83 & 2.36 & 4.41 & 2.16 & 2.36 & 44 & 52 \\
$\mathrm{~T}_{5}$ & 23.37 & 23.08 & 2.65 & 5.02 & 2.26 & 2.67 & 51 & 72 \\
$\mathrm{~T}_{6}$ & 23.80 & 23.25 & 3.27 & 5.65 & 2.60 & 2.81 & 73 & 81 \\
$\mathrm{~T}_{7}$ & 23.03 & 22.25 & 2.13 & 4.01 & 1.59 & 1.76 & 6 & 14 \\
$\mathrm{~T}_{8}$ & 22.77 & 22.08 & 1.73 & 3.60 & 1.50 & 1.55 & - & - \\
\hline $\mathrm{LSD}(0.05)$ & $\mathrm{NS}$ & 0.54 & 0.473 & 0.61 & 0.254 & 0.39 & & \\
$\mathrm{CV} \%$ & 1.52 & 1.38 & 8.12 & 7.81 & 5.38 & 10.30 & & \\
\hline
\end{tabular}

Note: $\mathrm{T}_{1}: \mathrm{N}_{40} \mathrm{P}_{9} \mathrm{~K}_{16} \mathrm{~S}_{6} \mathrm{Zn}_{1}(\mathrm{STB}) ; \mathrm{T}_{2}: \mathrm{N}_{50} \mathrm{P}_{9} \mathrm{~K}_{16} \mathrm{~S}_{6} \mathrm{Zn}_{1} ; \mathrm{T}_{3}: \mathrm{N}_{50} \mathrm{P}_{11} \mathrm{~K}_{16} \mathrm{~S}_{6} \mathrm{Zn}_{1} ; \mathrm{T}_{4}: \mathrm{N}_{50} \mathrm{P}_{9} \mathrm{~K}_{20} \mathrm{~S}_{6} \mathrm{Zn}_{1}$;

$\mathrm{T}_{5}: \mathrm{N}_{40} \mathrm{P}_{11} \mathrm{~K}_{20} \mathrm{~S}_{6} \mathrm{Zn}_{1} ; \mathrm{T}_{6}: \mathrm{N}_{50} \mathrm{P}_{11} \mathrm{~K}_{20} \mathrm{~S}_{6} \mathrm{Zn}_{1} ; \mathrm{T}_{7}: \mathrm{N}_{30} \mathrm{P}_{7} \mathrm{~K}_{12} \mathrm{~S}_{4.5} \mathrm{Zn}_{0.75} \mathrm{~kg} \mathrm{ha}^{-1}$; $\mathrm{T}_{8}$ : Control

\section{Cost and return}

Cost and return analysis demonstrated that maximum gross margin (Tk. 21550 ha $^{-1}$ in 2015 and Tk. 12214 ha $^{-1}$ in 2014) was obtained from $\mathrm{N}_{50} \mathrm{P}_{11} \mathrm{~K}_{20} \mathrm{~S}_{6} \mathrm{Zn}_{1}\left(\mathrm{~T}_{6}\right)$ followed by $\mathrm{T}_{5}$ fertilizer package (Table 4). Probably higher production and gross return (Tk. $72250 \mathrm{ha}^{-1}$ in 2015 and Tk. 61810 $\mathrm{ha}^{-1}$ in 2014) from this treatments resulted in higher economic return. Negative gross margin was recorded from the treatments $T_{8}$ (control) and $T_{7}$ which might be due to lower yield and gross return is less than the total variable costs in both the years.

Table 4. Cost and return analysis of B. aus rice as influenced by different fertilizer packages at Char Sadipur, Pabna during 2014 and 2015 cropping season

\begin{tabular}{lcccccc}
\hline \multirow{2}{*}{ Treatment } & \multicolumn{2}{c}{$\begin{array}{c}\text { Gross return } \\
(\text { Tk. ha }\end{array}$} & \multicolumn{2}{c}{$\begin{array}{c}\text { Total variable cost } \\
\left(\text { Tk.ha }^{-1}\right)\end{array}$} & \multicolumn{2}{c}{$\begin{array}{c}\text { Gross margin } \\
\left(\text { Tk. ha }^{-1}\right)\end{array}$} \\
\cline { 2 - 7 } & 2014 & 2015 & 2014 & 2015 & 2014 & 2015 \\
\hline $\mathrm{T}_{1}: \mathrm{N}_{40} \mathrm{P}_{9} \mathrm{~K}_{16} \mathrm{~S}_{6} \mathrm{Zn}_{1}(\mathrm{STB})$ & 40510 & 52240 & 48721 & 49770 & -8211 & 2470 \\
$\mathrm{~T}_{2}: \mathrm{N}_{50} \mathrm{P}_{9} \mathrm{~K}_{16} \mathrm{~S}_{6} \mathrm{Zn}_{1}$ & 42560 & 55740 & 49177 & 50278 & -6617 & 5462 \\
$\mathrm{~T}_{3}: \mathrm{N}_{50} \mathrm{P}_{11} \mathrm{~K}_{16} \mathrm{~S}_{6} \mathrm{Zn}_{1}$ & 45300 & 61380 & 49452 & 50553 & -4152 & 10827 \\
$\mathrm{~T}_{4}: \mathrm{N}_{50} \mathrm{P}_{9} \mathrm{~K}_{20} \mathrm{~S}_{6} \mathrm{Zn}_{1}$ & 50280 & 60430 & 49321 & 50422 & 959 & 10008 \\
$\mathrm{~T}_{5}: \mathrm{N}_{40} \mathrm{P}_{11} \mathrm{~K}_{20} \mathrm{~S}_{6} \mathrm{Zn}_{1}$ & 53150 & 68460 & 49140 & 50190 & 4010 & 18270 \\
$\mathrm{~T}_{6}: \mathrm{N}_{50} \mathrm{P}_{11} \mathrm{~K}_{20} \mathrm{~S}_{6} \mathrm{Zn}_{1}$ & 61810 & 72250 & 49596 & 50700 & 12214 & 21550 \\
$\mathrm{~T}_{7}: \mathrm{N}_{30} \mathrm{P}_{7} \mathrm{~K}_{12} \mathrm{~S}_{4.5} \mathrm{Zn}_{0.75}$ & 38190 & 47230 & 47600 & 48450 & -9410 & -1220 \\
$\mathrm{~T}_{8}:$ Control & 35190 & 41800 & 44250 & 44500 & -9060 & -2700 \\
\hline
\end{tabular}


Selling price: B. Aus: Grain $=$ Tk. $20.00 \mathrm{~kg}^{-1} ;$ Straw $=$ Tk. $3.00 \mathrm{~kg}^{-1}$

\section{Conclusion}

Based of this study, it can be concluded that fertilizer packages exerted significant effect on the growth and yield performance of B. Aus rice at the Char land of Pabna. The treatment $\mathrm{N}_{50} \mathrm{P}_{11} \mathrm{~K}_{20} \mathrm{~S}_{6} \mathrm{Zn}_{1}\left(\mathrm{~T}_{6}\right)$ demonstrated better performance on yield and yield attributes of $\mathrm{B}$. Aus than the other treatments. The maximum economic return in terms of gross return and gross margin was also recorded with the same fertilizer packages.

\section{References}

BBS. 2015.Yearbook of Agricultural Statistics of Bangladesh. Bangladesh Bureau of Statistics, Statistics Division, Ministry of Planning, Government of People's Republic of Bangladesh, Dhaka. Pp.39

BER. 2010.Bnagladesh Economic Review, Department of Finance, Ministry of Finance, Govt. of the People's Republic of Bangladesh, Dhaka.

Biswas, J.C., M. T. Ahmed and M.R. Islam. 2001. Lodging vs non-lodging in BRRI dhan 32. Bangladesh J. Train. Dev.14(1-2): 107-113.

Das, K., D.N. Medhi and B. Guha. 2003. Application of crop residues in combination with chemical fertilizers for sustainable productivity in rice (Oryza sativa)-wheat (Triticum aestivum) system. Indian J. Agron. 48 (1): 8-11.

Kazi, B. R., F. C. Oad and A. Lakho. 2002. Effect of irrigation frequencies on growth and yield of soybean. Pakistan J. Appl. Sci. 2(6): 661-662.

Mohamed, S. A. 1984. Effect of irrigation water and fertilization on yield and water use efficiency of corn plants in Fayoum Governorate. Moshtohor, Egypt Annual Agril. Sci. 20(2): 221-235.

Li, Z., S. R. Sarkat, K. S. Nayak and I. Ravi. 1997. Physiological effect of nitrogen application on aromatic rice. J. South China Agric. Univ. 18(3): 13-17.

Haque1, M. Z., M. S. A. Fakir, J. C. Biswas, S. S. Zaman and M. H. Rahman. 2016. Effect of irrigation, fertilizer package and planting density on growth and yield of Boro rice (var. BRRI dhan28). International J. of Emerging Trends in Sci. and Techn. 3(5): 3939-3946

Nadeem A., A. Iqbal, H. Z. Khan, M. K. Hanif and M. U. Bashir. 2010. Effect of different sowing dates on the yield and yield components of direct seeded fine rice (Oryza sativa L.) J. Plant Breeding and Crop Sci. 2(10): 312-315.

Pingali, P.L., M. Hossain and R. V. Gerpacio. 1997. The Asian rice bowls: The returning Crisis? CAB International, London and IRRI, MCPO box 3217. Makati 1271, Philippines.

Perrin, R. K., D. L.Winkelmen, E. R. Moscardi and J. R. Anderson. 1979. Economic Training Manual. Information Bulletin No. 27. CIMMYT, Mexico. p. 5.

Roy, R. K. and K. S. P. Singh. 1986. Response of pop-corn (Zea mays) to plant population and nitrogen. Indian J. Agron. 31(1): 87-92. 